\title{
METHOXYFLURANE FOR THE MANAGEMENT OF PHAEOCHROMOCYTOMA*
}

\author{
J. A. BAin, M.D., AND W. E. SPOEREL, M.D., F.R.C.P.(c)
}

THE CHOICE OF AN ANAESTHETIC AGENT that permits the organism to tolerate high levels of circulating catecholamines is a main consideration in the management of phaeochromocytoma. Anaesthetic techniques with diethyl ether were most frequently used; in a recent series, ${ }^{1}$ anaesthesia was in 'most cases maintained with nitrous oxide-oxygen supplemented with a narcotic or barbiturate to provide non-explosive anaesthetic conditions. The desire for a potent, safe, nonexplosive anaesthetic agent that would not sensitize the myocardium to adrenaline led us to try methoxyflurane (Penthrane) as the main anaesthetic agent for the management of a case of phaeochromocytoma.

A 12-year-old girl was admitted February 5, 1963, to Victoria Hospital for investigation of progressively severe, intermittent, throbbing headaches and occasional vomiting. A decreasing vision had led to the discovery of a severe retinopathy.

Physical examination revealed a slim, alert, well-developed girl weighing 89 pounds. The fundi showed advanced hypertensive retinopathy. The heart was clinically normal, pulse regular at 88 beats per minute. The blood pressure was 182/140 in the upper extremities and 192/146 in the lower. No other abnormalities were noted. Routine laboratory tests were normal. Under observation the patient's blood pressure remained around $170 / 120$ and Serpasil therapy had little effect.

Intravenous pyelogram, skull and chest X-rays, electrocardiogram, electroencephalogram, and Rogitine tests were all normal. The vanyl mandelic acid estimation was suggestive of phaeochromocytoma. Urine catecholamines were reported as being very high $(25.4 \mu \mathrm{g}$. of adrenaline and in excess of $1000 \mu \mathrm{g}$. of Noradrenaline in 24 hours). The diagnosis of phaeochromocytoma was made and the patient booked for an, exploratory laparotomy on March 1, 1963. The patient received 3 grains Nembutal at 6:30 a.m. and $50 \mathrm{mg}$. Demerol and 0.3 $\mathrm{mg}$. atropine for premedication at 7:00 a.m. At 8:00 a.m. anaessthesia was cautiously induced with $250 \mathrm{mg}$. sodium thiopentone and the patient was intubated after $40 \mathrm{mg}$. succinylcholine with a no. 7 cuffed endotracheal tube. Anaesthesia was maintained with methoxyflurane 0.5 per cent using a "Pentec" vaporizer, nitrous oxide $2 \mathrm{~L} . / \mathrm{min}$., oxygen $2 \mathrm{~L} . / \mathrm{min}$. (see the anaesthesia record). The patient was ventilated with the Bird Assistor-Controller. Additional relaxation was obtained with an intravenous infusion of 0.1 per cent succinylcholine chloride used intermittently.

The blood pressure was measured directly through an arterial needle attached to a Tycos manometer; the electrocardiogram was monitored continually on an oscilloscope. Rogitine $1 \mathrm{mg}$. was given intermittently intravenously for blood pressure rises over $200 \mathrm{~mm}$. Hg mean pressure for more than 2-3 minutes and a total of $7 \mathrm{mg}$. Rogitine was used.

The tumour was identified anterior and medial to the $p_{2}$ left adrenal gland adjacent to the aorta and was removed leaving the adrenal gland intact. Dissection was difficult and required considerable manipulation of the tumour. After removal of the tumour a gradual fall in blood pressure occurred and Noradrenaline infusion $(4 \mathrm{mg}$. Levophed

\footnotetext{
"From the Department of Anaesthesia, University of Western Ontario, and Victoria Hospital, London, Ontario.
} 


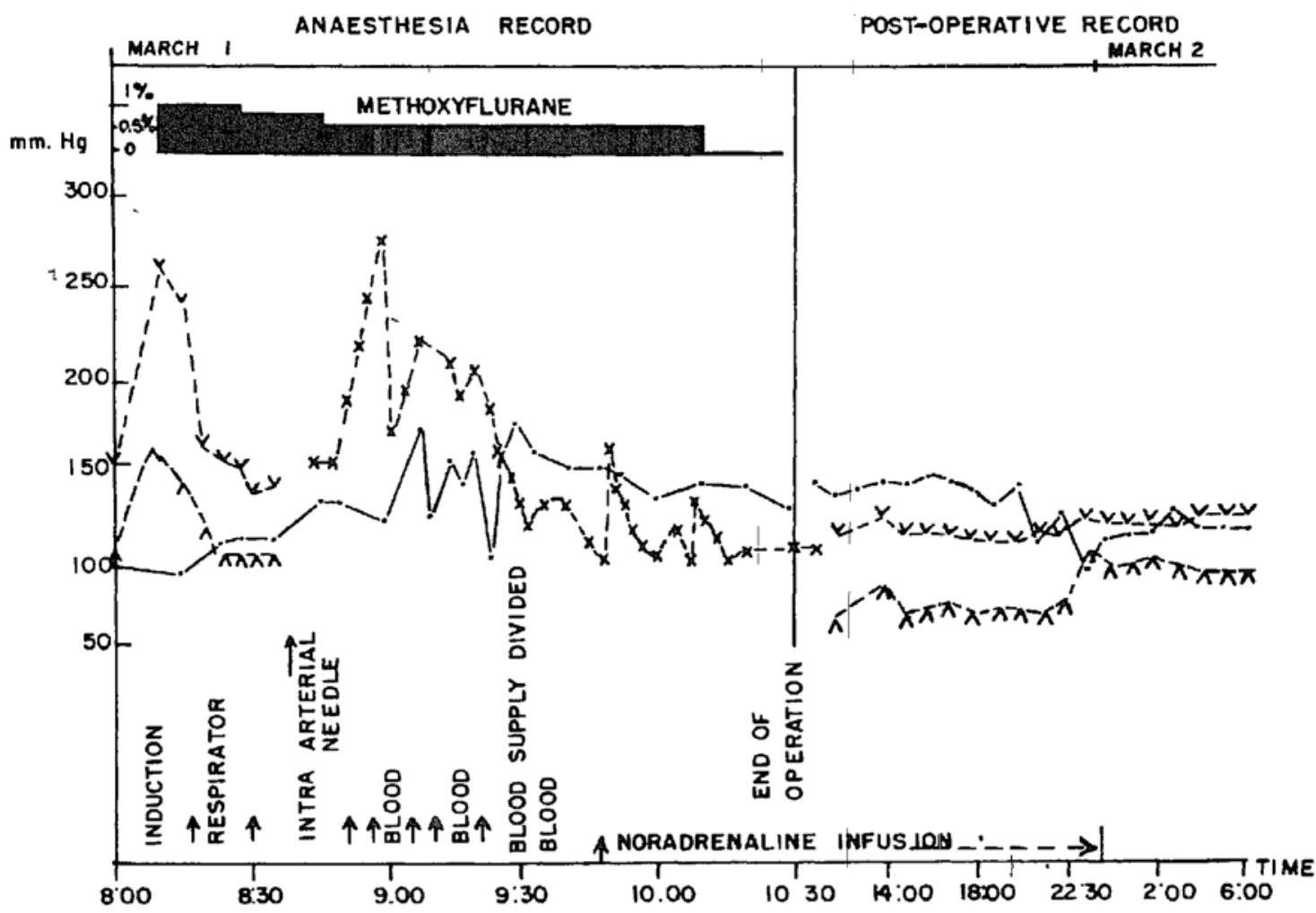

Figure 1. Anaesthesia record and postoperative record. Methoxyflurane concentration in per cent (Pentec). Dashed line with "vees" represents the blood pressure; dashed line with "crosses," the direct mean arterial pressure; solid line with dots, the heart rate; and the arrows mark the injection of $1 \mathrm{mg}$. Rogitine intravenously.

in $500 \mathrm{ml}$. solution) was required to maintain the blood pressure between 100 and 120 $\mathrm{mm}$. Hg. During the course of anaesthesia the cardiac rhythm remained regular, except for occasional extrasystoles and electrocardiogram patterns interpreted as left ventricular strain at peak blood pressures during manipulation of the tumour. A total of $300 \mathrm{ml}$. of the noradrenaline infusion was required for $14 \frac{1}{2}$ hours postoperatively; the first $200 \mathrm{ml}$. were absorbed in the first two hours after the tumour was removed. , The patient's blood pressure remained approximately $120 / 80$ for the first 48 hours postoperatively, then gradually rose to about $150 / 100$ the third postoperative day, returning to $160 / 74$ on the fifth postoperative day. The pulse remained elevated between 100 and 130 beats per minute until the eighth postoperative day, when it slowed to between 90 and 100 beats per minute. There were no other complications and the patient was discharged on the fourteenth postoperative day.

The tumour was a benign phaeochromocytoma and weighed 71 grams. It contained $0.99 \mathrm{mg}$. adrenaline per $\mathrm{gm}$. tumour and $1.8 \mathrm{mg}$. noradrenaline per gm. tumour.

On the fourth postoperative day the urinary catecholamines were determined and reported to be at the upper limit of normal.

At the termination of the operation the surgeon commented that the operation went more smoothly than previous similar , cases. This was particularly remarkable in view of the rather difficult dissection of this relatively large tumour.

Though methoxyflurane is considered compatible with adrenaline in man, serious arrhythmias have been reported with this combination in the $\operatorname{dog}^{2,3}$ In our hospital, methoxyflurane has been used as the main anaesthetic agent in approximately 1000 patients; cardiac arrhythmia had not been evident in the 
many cases where adrenaline was used by the surgeon to aid haemostasis. We therefore felt justified in using methoxyflurane in the presence of high levels of internal catecholamines. The smooth anaesthetic course of this patient must be attributed in part to the anaesthetic agent and we are encouraged to use methoxyflurane in the future in similar cáses.

\section{SUMMARY}

A 71-gram phaeochromocytoma was removed in a 12-year-old girl under methoxyflurane anaesthesia. No significant cardiac arrhythmias were seen in spite of marked hypertensive episodes. The patient made an uneventful recovery.

\section{ACKNOWLEDGMENTS}

The authors wish to thank Professor A. D. McLachlin for permission to publish this case. The catecholamine determinations were done by Professor C. W. Gowdey, Department of Pharmacology, University of Western Ontario. The "Pentec" vaporizer was made available by Canam Surgical Services through the courtesy of Abbott Laboratories Limited.

\section{RÉSUME்}

Quand il s'agit de manipuler un phéochromôcytome, il est de première importance de choisir un agent anesthésique compatible avec la présence dans lorganisme de grandes quantités de catécholamines circulantes. Bien que, chez l'homme, le méthoxyflurane et l'adrénaline soient compatibles, chez le chien, des auteurs ont observé des arythmies sérieuses en employant cette association. Devant le fait que, dans notre hôpitål, nous avons employé le méthoxyflurane comme agent anesthésique principal chez environ 1,000 malades et devant le fait que nous n'avons pas noté d'arythmies chez plusieurs malades où le chirurgien avait employé de l'adrénaline pour faciliter l'hémostase, nous nous sommes crus justifiés d'employer le méthoxyflurane en présence de taux élevés de cathécholamines endogènes.

Chez une jeune fille de 12 ans, sous anesthésie au méthoxyflurane, nous avons enlevé un phéochromocytome de 71 grammes. En dépit de l'apparition d'épisodes hypertensives importantes, nous n'avons pas noté d'arythmies cardiaques sérieuses. L'anesthésie sans incidents de cette malade est attribuable, en partie, à l'agent anesthésique et, dans l'avenir, pour des cas semblables, nous sommes incités à employer le méthoxyflurane.

\section{REFERENCES}

1. Price, J. \& Secher, $O$ Anaesthetic Management of Pheochromocytoma. Acta Anaesth Scandinav. 5: 153 (1961).

2. Bamforth, B. J.; Siebecker, K. L.; Kraemer, R.; \& Orth, O. S. Effect of Epinephrine on the Dog Heart during Methoxyflurane Anaesthesia. Anesthesiology 22: 169 (1961).

3. Israel, J. S.; Wiswick, V G.; \& DobkiN, A. B. Effect of Epinephrine on Cardiac Rhythm during Anaesthesia with Methoxyflurane and Trifluoroethyl Vinyl Ether. Acta Anaesth. Scanidinav. 6: 7 (1962). 